\title{
Mannose-binding lectin protein and its association to clinical outcomes in COPD: a longitudinal study
}

Jyotshna Mandal ${ }^{1 \dagger}$, Bijaya Malla ${ }^{1 \dagger}$, Rudi Steffensen ${ }^{2}$, Luigi Costa $^{1}$, Adrian Egli $^{3}$, Marten Trendelenburg ${ }^{4}$, Francesco Blasi ${ }^{5}$, Kostantinos Kostikas ${ }^{6}$, Tobias Welte ${ }^{7}$, Antoni Torres ${ }^{8}$, Renaud Louis ${ }^{9}$, Wim Boersma ${ }^{10}$, Branislava Milenkovic ${ }^{11}$, Joachim Aerts ${ }^{12}$, Gernot G. U. Rohde ${ }^{13}$, Alicia Lacoma ${ }^{14}$, Katharina Rentsch ${ }^{15}$, Michael Roth ${ }^{1}$, Michael Tamm ${ }^{1}$ and Daiana Stolz ${ }^{1 *}$

\begin{abstract}
Background: Functional deficiency of mannose-binding lectin (MBL) may contribute to the pathogenesis of chronic obstructive pulmonary disease. We hypothesized that specific MBL2 gene polymorphisms and circulating MBL protein levels are associated with clinically relevant outcomes in the Predicting Outcome using systemic Markers In Severe Exacerbations of COPD PROMISE-COPD cohort.

Methods: We followed 277 patients with stable COPD GOLD stage II-IV COPD over a median period of 733 days (IQR 641-767) taking survival as the primary outcome parameter. Patients were dichotomized as frequent ( $\geq 2$ AECOPD/year) or infrequent exacerbators. Serum MBL levels and single nucleotide polymorphisms of the MBL2 gene were assessed at baseline.
\end{abstract}

Results: The MBL2-HYPD haplotype was significantly more prevalent in frequent exacerbators (OR: 3.33; $95 \%$ $\mathrm{Cl}, 1.24-7.14, p=0.01)$. The median serum MBL concentration was similar in frequent $(607 \mathrm{ng} / \mathrm{ml}$, [IQR; 363.0-896.0 $\mathrm{ng} / \mathrm{ml}])$ and infrequent exacerbators (615 ng/ml, [IQR; $371.0-942.0 \mathrm{ng} / \mathrm{ml}])$. Serum MBL was not associated with lung function characteristics or bacterial colonization in sputum. However, high serum MBL at stable state was associated with better survival compared to low MBL ( $p=0.046$, log rank test).

Conclusions: In COPD, the HYPD haplotype of MBL2 gene is associated with frequent exacerbations and high serum MBL is linked to increased survival.

The PROMISE-COPD study was registered at www.controlled-trials.com under the identifier ISRCTN99586989.

Keywords: Lung function, Haplotypes, Exacerbation, Survival rate

\section{Background}

The World Health Organization projects that Chronic Obstructive Pulmonary Disease (COPD) will become the third leading cause of death worldwide by 2030 [1]. The increasing COPD mortality might be associated with the aging population, tobacco use, air pollution, and respiratory infection [2]. In COPD patients, exacerbation causes a mounting economic burden by frequent hospitalization

\footnotetext{
* Correspondence: daiana.stolz@usb.ch

${ }^{\dagger}$ Equal contributors

${ }^{1}$ Clinic of Pulmonary Medicine and Respiratory Cell Research, University Hospital Basel, Petersgraben, 44031 Basel, Switzerland

Full list of author information is available at the end of the article
}

and by chronic disability. Recurrent exacerbations are associated with accelerated lung function deterioration, reduction of quality of life, and decreased survival in COPD. Some COPD patients are susceptible to exacerbations requiring frequent hospital visits and hospitalizations. Thus, frequent exacerbation has been recognised as a major clinically relevant COPD phenotype [3]. The identification of predictive markers for these episodic and recurrent worsening of symptoms may help to improve the management of COPD [4].

Mannose binding lectin (MBL) is an important factor in the innate immune system that binds to carbohydrate regions of bacterial cell walls and viral capsules. Binding 
of $\mathrm{MBL}$ protein activates the complement system via MBL-associated serine proteases, eventually leading to the clearance of pathogens [5]. Polymorphisms of the human $M B L 2$ gene are associated with deficiency of serum MBL protein levels that may cause susceptibility to infection [4]. The polymorphisms that control the serum MBL protein levels are located in the promoter region, and in exon 1 of the human $M B L 2$ gene [6]. In general, carriers with different polymorphisms in exon 1 present low MBL serum levels. Not only that MBL2 polymorphisms and serum MBL deficiency have been found to be associated with susceptibility to bacterial and viral diseases, they have also been linked to noncommunicable diseases such as cystic fibrosis, and COPD [7, 8]. Serum MBL levels for genotypes $X A / O$ and $O / O$ had a mean serum level below $100 \mathrm{ng} / \mathrm{ml}$ [4]. Furthermore, COPD patients with the "O"-allele are reported to suffer from recurrent infective exacerbations. Thus, we hypothesized that specific $M B L 2$ polymorphisms and circulating MBL levels are associated with clinically relevant outcomes in COPD. To prove our hypothesis, we evaluated serum MBL levels and polymorphisms in the $M B L 2$ gene in a well-characterized cohort of COPD patients.

\section{Methods}

\section{Study population}

This nested cohort study included 277 patients enrolled in the investigator initiated PROMISE-COPD study (Predicting Outcome using systemic Markers In Severe Exacerbations of COPD). The Patients were recruited at a baseline visit after consent from 11 primary and tertiary study centres across Europe during 2008-2011. The study was approved by the Ethics Committee Beider Basel (EKBB 295/07), and was registered at www.controlled-trials.com (ISRCTN99586989). The patients had to be $>40$ years, smoking history of $\geq 10$ pack years, and be at a stable state defined as clinical stability for 4 weeks after resolution of the last exacerbation. Patients with pulmonary conditions other than COPD (asthma, bronchiectasis, cystic fibrosis), immunosuppressive diseases, chronic steroid use $>10 \mathrm{mg} /$ day prednisolone-equivalent, musculo-skeletal process preventing ambulation, and estimated life expectancy $<6$ months were excluded.

\section{Baseline and scheduled visits assessment}

COPD exacerbation was defined as an acute change from baseline in dyspnea, cough, and/or sputum production beyond normal day-to-day variation that necessitates use of antibiotics, glucocorticoids, or both [9]. Spirometry was performed following American Thoracic Society guidelines. Patients were categorized into COPD stages (II-IV); (post-bronchodilator FEV1/FVC $<70 \%$; FEV $1<80 \%$ predicted) and grouped according to the
GOLD 2011/ 2013 classification [2, 10]. Patients were grouped into infrequent exacerbators (0-1 exacerbation/ year) and frequent exacerbators ( $\geq 2$ exacerbations/year). Outcome (all-cause mortality) was evaluated by contacting the patients, family physicians, or by checking public registries. The median follow-up time of the study was 733 days (IQR; 641-767 days). Patients answered the St. George's Respiratory Questionnaire (SGRQ) and the Short Form Health Survey (SF-36) at the time of enrolment. Spontaneously expectorated sputum samples were obtained and were examined by using standard microbiology culture techniques. Sputum samples were examined for Gram staining. Good sputum quality was defined as $<25$ epithelial cells in 100× augmentation [11]. Serum samples for MBL measurements and genotyping were collected at stable state.

\section{Genotyping of $M B L 2$ gene}

Three single nucleotide polymorphisms (SNPs) within the $M B L 2$ promoter $(H / L ;-550, \operatorname{rs} 11003125),(X / Y ;-221$, rs7096206), $(P / Q ;+4$, rs7095891) and three SNPs in $M B L 2$ exon 1 ( $A / D$; codon52, rs5030737), $(A / B$; codon54, rs1800450), ( $A / C$; codon57, rs1800451) were determined by real-time polymerase chain reaction (RT-PCR) using minor-groove-binder (MGB) TaqMan probes (Applied Biosystems, Foster City, CA, USA). Genotyping was achieved by end-point fluorescence using SDS software (version 2.3) [12, 13]. The SNPs used to characterise the $M B L 2$ alleles are listed in Table 1.

\section{Measurement of serum MBL concentration}

Serum MBL was measured in duplicate by enzyme-linked immunosorbent assay ( $\&$ D Systems, Inc., Minneapolis, MN, USA) following the manufacturer protocol. The serum was assigned as "low" for MBL levels below the $75^{\text {th }}$ quartile $(<934 \mathrm{ng} / \mathrm{ml})$, and as "high" above the $75^{\text {th }}$ percentile $(\geq 934 \mathrm{ng} / \mathrm{ml})[14,15]$.

\section{Statistical analysis}

Statistical analysis was done by SPSS (Version 21, IBM Corp., NY, USA), and $p$-values less than 0.05 were considered significant. Baseline data are presented as mean or median values (continuous variables), while discrete data are as percentages. The association of $M B L 2$ polymorphisms and low and high serum MBL, with exacerbation was tested by Chi-square test. The Metric data was analysed by Students-t-test or Mann-Whitney-U test. The Kaplan-Meier log rank test was used to test the null hypothesis: "no difference in time to death".

\section{Results}

\section{Study population}

Clinical characteristics of patients are summarized in Table 2, showing a mean age of 68 years with $70 \%$ being 
Table 1 Mannose-binding lectin 2 (MBL2) gene polymorphisms in patients with infrequent and frequent exacerbation

\begin{tabular}{|c|c|c|c|}
\hline $\begin{array}{l}\text { Single nucleotide } \\
\text { polymorphisms }\end{array}$ & $\begin{array}{l}\text { Infrequent } \\
\text { exacerbation n (\%) }\end{array}$ & $\begin{array}{l}\text { Frequent } \\
\text { exacerbation n (\%) }\end{array}$ & $p$ value \\
\hline \multicolumn{4}{|l|}{ Promoter region } \\
\hline $\begin{array}{l}\mathrm{HL}\left(-550 \mathrm{G}>\mathrm{C}_{i}\right. \\
\mathrm{rs} 11003125)\end{array}$ & & & 0.03 \\
\hline$C / C(L / L)$ & 77 (50.0) & $46(37.4)$ & \\
\hline $\mathrm{G} / \mathrm{C}(\mathrm{H} / \mathrm{L})$ & $57(37.0)$ & $48(39.0)$ & \\
\hline $\mathrm{G} / \mathrm{G}(\mathrm{H} / \mathrm{H})$ & $20(13.0)$ & 29 (23.6) & \\
\hline $\begin{array}{l}\text { YX (-221 G > C; } \\
\text { rs7096206) }\end{array}$ & & & 0.64 \\
\hline $\mathrm{G} / \mathrm{G}(\mathrm{Y} / \mathrm{Y})$ & $92(59.7)$ & $80(65.0)$ & \\
\hline $\mathrm{G} / \mathrm{C}(\mathrm{Y} / \mathrm{X})$ & $53(34.4)$ & $36(29.3)$ & \\
\hline$C / C(X / X)$ & $9(5.8)$ & $7(5.7)$ & \\
\hline \multicolumn{4}{|l|}{ Exon 1} \\
\hline $\begin{array}{l}\mathrm{PQ}(+4 \mathrm{C}>\mathrm{T} \\
\text { rs7095891) }\end{array}$ & & & 0.65 \\
\hline$C / C(P / P)$ & 89 (57.8) & 77 (62.6) & \\
\hline $\mathrm{C} / \mathrm{T}(\mathrm{P} / \mathrm{Q})$ & $47(30.5)$ & $35(28.5)$ & \\
\hline $\mathrm{T} / \mathrm{T}(\mathrm{Q} / \mathrm{Q})$ & $18(11.7)$ & $11(8.9)$ & \\
\hline $\begin{array}{l}\mathrm{A} / \mathrm{D}(+223 \mathrm{C}>\mathrm{T} \\
\text { rs5030737) }\end{array}$ & & & 0.03 \\
\hline $\mathrm{A} / \mathrm{A}(\mathrm{C} / \mathrm{C})$ & $124(91.9)$ & $119(83.8)$ & \\
\hline $\mathrm{A} / \mathrm{D}(\mathrm{C} / \mathrm{T})$ & $12(7.8)$ & $21(17.1)$ & \\
\hline $\mathrm{D} / \mathrm{D}(\mathrm{T} / \mathrm{T})$ & $0(0)$ & $1(0.8)$ & \\
\hline \multicolumn{4}{|l|}{$\begin{array}{l}\mathrm{A} / \mathrm{B}(+230 \mathrm{G}>\mathrm{A} ; \\
\mathrm{rs} 1800450)\end{array}$} \\
\hline $\mathrm{A} / \mathrm{A}(\mathrm{G} / \mathrm{G})$ & $129(83.8)$ & $106(86.2)$ & 0.79 \\
\hline $\mathrm{A} / \mathrm{B}(\mathrm{G} / \mathrm{A})$ & $23(14.9)$ & $15(12.2)$ & \\
\hline $\mathrm{B} / \mathrm{B}(\mathrm{A} / \mathrm{A})$ & $2(1.3)$ & $2(1.6)$ & \\
\hline \multicolumn{4}{|l|}{$\begin{array}{l}\mathrm{A} / \mathrm{C}(+239 \mathrm{G}>\mathrm{A} \\
\mathrm{rs} 1800451)\end{array}$} \\
\hline $\mathrm{A} / \mathrm{A}(\mathrm{G} / \mathrm{G})$ & $146(94.8)$ & $119(96.7)$ & 0.27 \\
\hline $\mathrm{A} / \mathrm{C}(\mathrm{G} / \mathrm{C})$ & $8(5.2)$ & $3(2.4)$ & \\
\hline$C / C(A / A)$ & $0(0)$ & $1(0.8)$ & \\
\hline
\end{tabular}

The distribution of each polymorphism in promoter and exon 1 region of $M B L 2$ is shown in infrequent and frequent exacerbation. The $H L$ and $A D$ polymorphisms were significantly different between exacerbation groups. The $r$ number for each SNP represents the reference Single nucleotide polymorphisms identification number

male. The majority of patients were ex-smokers with a median cigarette consumption of 40 pack-years. The median duration of COPD was 60 months and 185 (66.8\%) patients had exacerbations ranging from 1-15 physician visits in previous years. Of those patients, $35.9 \%$ had a history of hospitalization in the previous year, $9 \%$ of which required intensive care unit stay. GOLD classification showed that $50 \%$ of the patients had moderate COPD (GOLD II; $46.6 \%$ ). 123 (44.4\%) patients were classified as frequent exacerbators.

\section{Serum MBL levels and association with patient characteristics}

The median serum MBL level in our study cohort was $(612 \mathrm{ng} / \mathrm{ml} ;[85-2,363 \mathrm{ng} / \mathrm{ml}])$. There was no correlation of serum MBL and $\mathrm{FEV}_{1} \%$ pred. post $\mathrm{BD}(p=0.36)$. The median serum MBL in COPD II patients was $(590 \mathrm{ng} / \mathrm{ml}$, [IQR; 106-2106 ng/ml]), COPD III (659 ng/ml, [IQR; 942,363 ng/ml]), and COPD IV (491 ng/ml, [IQR; 85$2,120 \mathrm{ng} / \mathrm{ml}])$. There was no difference in serum $\mathrm{MBL}$ level between frequent and infrequent exacerbators (median, $612 \mathrm{ng} / \mathrm{ml}$ vs. $615 \mathrm{ng} / \mathrm{ml} ; p=0.59$ ). MBL level showed no difference between patients who died from COPD (4.33\%) and patients who died due to other reasons (6.13 \%) (median, $625 \mathrm{ng} / \mathrm{ml}$ vs. $590 \mathrm{ng} / \mathrm{ml} ; p=0.49)$.

At stable state, 90 patients provided sputum of which 26 yielded positive culture results. The isolated organisms were: Pseudomonas aeruginosa $(n=10)$, Enterobacter spp. $(n=7)$, Streptococcus pneumoniae $(n=6)$, Haemophilus influenzae $(n=6)$, Moraxella catarrhalis $(n=4)$, and Staphylococcus aureus $(n=1)$. Patients with and without evidence of chronic bacterial colonization had comparable circulating MBL levels (754 ng/ml; IQR, 559-1113 ng/ml vs. $627 \mathrm{ng} / \mathrm{ml}$; IQR, 455$915 \mathrm{ng} / \mathrm{ml}, p=0.30)$. Serum $\mathrm{MBL}$ was similar in colonization with Gram positive vs. Gram negative staining (762 ng/ml, [IQR 559-909 ng/ml] vs. $942 \mathrm{ng} / \mathrm{ml}$, [IQR, 637-1,294 ng/ml], $p=0.38$ ).

The distribution of co-morbid state was comparable between frequent and infrequent exacerbators and was independent of serum MBL. A logistic regression analysis was performed to evaluate the serum MBL and its association to patient characteristics including exacerbation rate. Serum MBL was not associated with COPD duration, age, BMI, GOLD stage, post- $\mathrm{FEV}_{1} \%$ predicted, SGRQ total score, arterial hypertension, $M B L 2 H / L$ allele, $M B L 2$ exon 1 polymorphisms $(A / A$, vs. $A / O, O / O)$ $(p>0.05)$. In the low serum MBL group, 22 patients (10.6\%) deceased during the study period as compared to 2 patients $(2.9 \%)$ in the high serum MBL group. The hazard ratio for death within 2 years for patients with high serum MBL was 4.0 (95 \% CI, 0.94-50; $p=0.05$ ). The survival rate in patients with high serum MBL was higher than in those with low serum MBL (Fig. 1, $p=0.046$, log rank test).

\section{Polymorphisms in MBL2 gene}

Analysing the frequency of SNPs in the $M B L 2$ promoter region $(H / L)$, we observed a statistically significant difference with twenty nine (23.6 \%) of the 123 frequent exacerbators being $H / H$ homozygotes compared to twenty (13.0 \%) in 154 infrequent exacerbators $(p=0.043)$. Similarly, the distribution of the $A / D$ allele was significantly different in frequent and infrequent exacerbators $(p=0.03)$. However, there was no difference in 
Table 2 Demographic characteristics of study population

\begin{tabular}{|c|c|}
\hline \multicolumn{2}{|l|}{ Total $n=277$} \\
\hline Patient Characteristics & Values ${ }^{\mathrm{a}}$ \\
\hline Age (years) & $67.8 \pm 9.5$ \\
\hline Sex (Male) & $190(68.6)$ \\
\hline Race (Caucasian) & $274(98.9)$ \\
\hline BMI $\left(\mathrm{kg} / \mathrm{m}^{2}\right)$ & $26.3(23.3-29.4)$ \\
\hline \multicolumn{2}{|l|}{ Smoking status } \\
\hline Current smokers, (n) \% & $74(26.7)$ \\
\hline Median Pack-years, median, IQR & $50(35-80)$ \\
\hline \multicolumn{2}{|l|}{ Comorbidities } \\
\hline Congestive heart disease, $\%$ & 17.5 \\
\hline Diabetes mellitus, \% & 12.9 \\
\hline Liver disease, \% & 2.9 \\
\hline Malignant solid tumour, \% & 4.0 \\
\hline Arterial hypertension, \% & 56.4 \\
\hline Pulmonary arterial hypertension, \% & 8.0 \\
\hline \multicolumn{2}{|l|}{$\begin{array}{l}\text { History of exacerbations in COPD } \\
\text { patients in previous years }\end{array}$} \\
\hline $\begin{array}{l}\text { Median duration of COPD (months), } \\
\text { median IQR }\end{array}$ & $84(44.5-130)$ \\
\hline $\begin{array}{l}\text { Duration of physician-diagnosed COPD } \\
\text { (months), median, IQR }\end{array}$ & $60(29-120)$ \\
\hline $\begin{array}{l}\text { Required unscheduled urgent physician } \\
\text { visit, median, IQR }\end{array}$ & $1(0-2)$ \\
\hline Required hospitalization, median, IQR & $0(0-1)$ \\
\hline Antibiotics use, median, IQR & $1(0-1)$ \\
\hline \multicolumn{2}{|l|}{ Current medication for COPD } \\
\hline SABA + SAMA, \% & 20.6 \\
\hline$L A B A+I C S, \%$ & 73.5 \\
\hline \multicolumn{2}{|l|}{ Single drug inhaler } \\
\hline SABA, $\%$ & 31.4 \\
\hline LABA, \% & 12.27 \\
\hline SAMA, \% & 6.2 \\
\hline LAMA, \% & 71.7 \\
\hline ICS, \% & 11.7 \\
\hline \multicolumn{2}{|l|}{ Lung function tests } \\
\hline FEV1,L post-BD, mean \pm S.D. & $1.4 \pm 0.6$ \\
\hline FEV1 \% predicted post-BD, mean \pm S.D. & $48.2 \pm 17.5$ \\
\hline FVC,L post-BD, mean \pm S.D. & $2.9 \pm 3.8$ \\
\hline FVC $\%$ predicted post-BD, mean \pm S.D. & $77.9 \pm 23.2$ \\
\hline FEV1/FVC post-BD, mean \pm S.D. & $48.0 \pm 13.6$ \\
\hline \multicolumn{2}{|l|}{ GOLD Stages } \\
\hline GOLD II, (n) \% & $129(47.3)$ \\
\hline GOLD III, (n) \% & $104(38.1)$ \\
\hline GOLD IV, (n) \% & $40(14.6)$ \\
\hline
\end{tabular}

SGRQ - Quality of life

Symptoms score, median IQR
Table 2 Demographic characteristics of study population (Continued)

\begin{tabular}{|c|c|}
\hline Activity score, median IQR & $59.4(42.4-79.2)$ \\
\hline Impact score, median IQR & $30.0(18.3-46.5)$ \\
\hline Total score, median IQR & $41.8(29.5-57.8)$ \\
\hline \multicolumn{2}{|l|}{ SF-36 Health Survey } \\
\hline Physical Function, median IQR & $50.0(25.0-70.0)$ \\
\hline Role Function, median IQR & $50.0(0.0-100.0)$ \\
\hline Role Emotional, median IQR & $100.0(8.3-100.0)$ \\
\hline Social Function, median IQR & $75.0(50.0-100.0)$ \\
\hline Mental Health, median IQR & $65.0(55.0-80.0)$ \\
\hline Body Pain, median IQR & $74.0(51.0-100.0)$ \\
\hline Vitality, median IQR & $50.0(37.5-62.5)$ \\
\hline General Health, median IQR & $45.0(28.3-65.0)$ \\
\hline \multicolumn{2}{|l|}{ Exercise performance } \\
\hline 6MWD, $m$, mean \pm S.D. & $375.5 \pm 102.6$ \\
\hline $\begin{array}{l}\text { Peripheral Oxygen saturation at rest, } \\
\text { mean } \pm \text { S.D. }\end{array}$ & $94.5 \pm 2.7$ \\
\hline $\begin{array}{l}\text { Lowest oxygen saturation during test, } \\
\text { mean } \pm \text { S.D. }\end{array}$ & $89.6 \pm 6.0$ \\
\hline Heart rate at rest (beats/min), mean \pm S.D. & $80.8 \pm 14.7$ \\
\hline $\begin{array}{l}\text { Highest heart rate during test (beats } / \mathrm{min} \text { ), } \\
\text { mean } \pm \text { S.D. }\end{array}$ & $105.9 \pm 19.49$ \\
\hline 6 min' walk BORG score, median IQR & $4(3-6)$ \\
\hline BODE index, median IQR & $3(1-4)$ \\
\hline \multicolumn{2}{|l|}{ Serum MBL level } \\
\hline $\begin{array}{l}\text { Serum MBL concentration, ng/ml, } \\
\text { median, IQR }\end{array}$ & $612(365.5-933.0)$ \\
\hline $\begin{array}{l}\text { Low serum MBL level (<75th quartile; } \\
<934 \mathrm{ng} / \mathrm{ml}) \text {, (n) \% }\end{array}$ & $208(75.1)$ \\
\hline $\begin{array}{l}\text { High serum MBL level ( } \geq 75 \text { th percentile; } \\
\geq 934 \mathrm{ng} / \mathrm{ml} \text { ), (n) } \%\end{array}$ & $69(24.9)$ \\
\hline \multicolumn{2}{|c|}{ 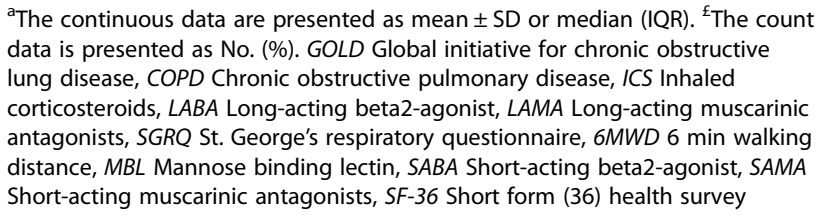 } \\
\hline
\end{tabular}

exacerbation frequency for the other allele $(Y / X, P / Q$, $A / B, A / C, p>0.05$ for all).

In order to test if $M B L$ genotypes of exon 1 alleles are associated with COPD outcomes (exacerbation frequency), we grouped the genotypes into two: where the $M B L 2$ polymorphisms $52(A / D), 54(A / B)$, and $57(A / C)$ alleles can be grouped and referred as genotype " $O$ " that is considered to express low serum MBL, while the other alleles were assigned as genotype " $A$ " that express normal serum MBL levels [16]. In our patient cohort, the frequency of the "O" genotype was not significantly different in infrequent and frequent exacerbators $(27.9 \%$ 


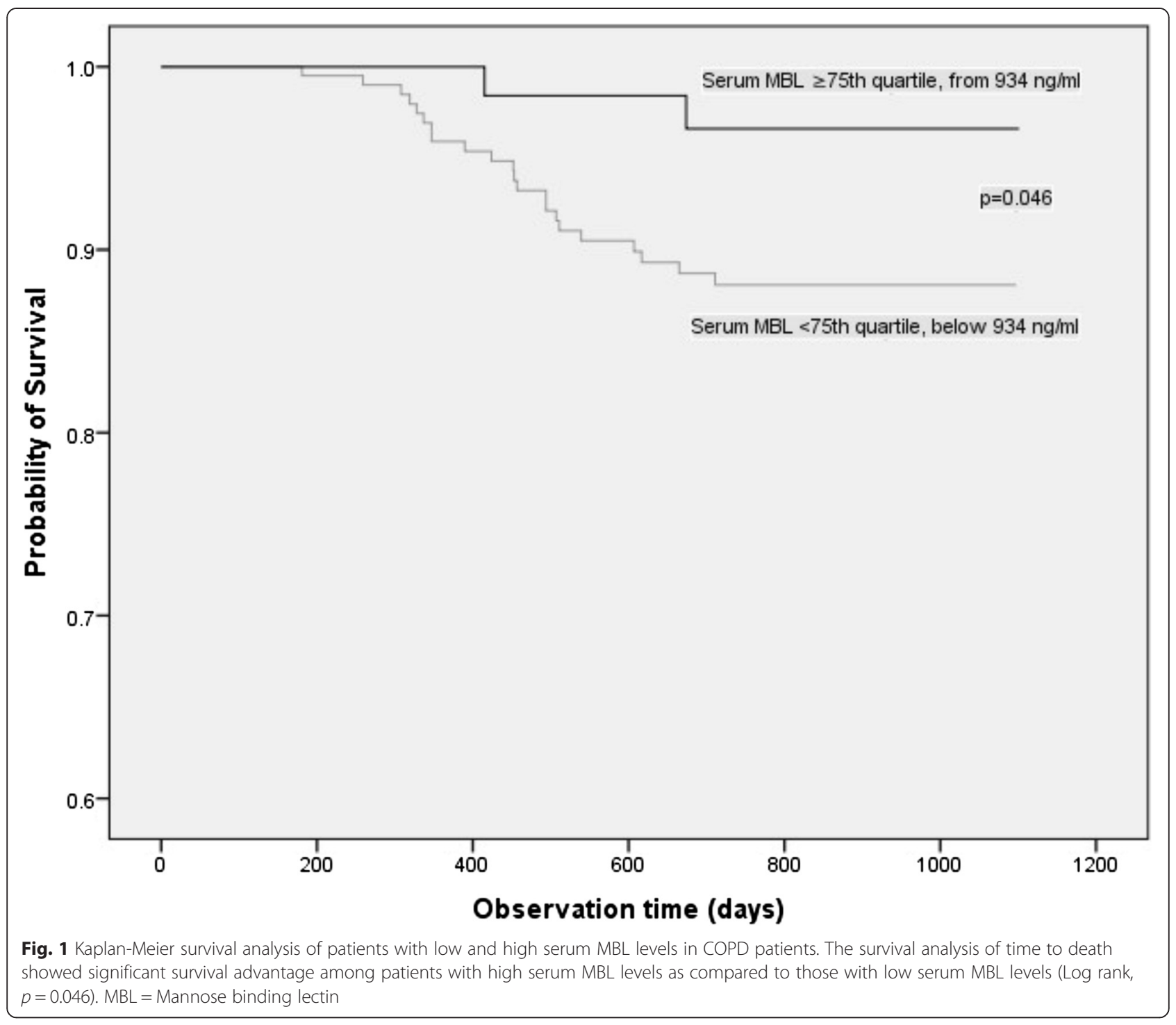

vs. $31.7 \%$; $p=0.47$ ), and, the serum MBL level was independent of exon 1 alleles $(p=0.39)$.

In a second approach, we combined the promoter $X / Y$ allele with the pooled exon $1 \mathrm{~A} / \mathrm{O}$ alleles which is considered to change serum MBL level [17]. In our cohort, the $X A / X A$ and $Y O / Y O$ genotypes were the least frequent, however the distribution of all possible six genotypes was not different between frequent and infrequent exacerbators $(p>0.05$, for all), and no association with serum MBL was observed $(p>0.05)$ (Additional file 1: Table S1).

\section{Frequencies of $M B L 2$ haplotypes and serum $M B L$}

The MBL2 haplotype frequency in infrequent and frequent exacerbators is summarized in Table 3. To further investigate the serum MBL and its function, we compared the MBL haplotypes to serum MBL concentration and patient's characteristics. Haplotypes (LYPB, HYPD, and $L Y Q C$ ) that code for low serum MBL were less frequent represented by $15.6 \%$ of the cohort. Based on an earlier report we categorized the $M B L 2$ polymorphisms as: "high", "intermediate", and "low" serum MBL concentration expressing genotypes [18-21], and compared it to exacerbation frequency [15]. However, in this cohort neither the exacerbation frequency nor the serum MBL was different across "MBL concentration genotypes". Similar median values of serum MBL were observed in infrequent exacerbators $(614.5 \mathrm{ng} / \mathrm{ml}$; IQR, 371.0$942.0 \mathrm{ng} / \mathrm{ml})$, and frequent exacerbators $(607.0 \mathrm{ng} / \mathrm{ml}$; IQR, 363.0-896.0 $\mathrm{ng} / \mathrm{ml} ; p=0.91)$. Patients with the HYPD haplotype had similar hospitalization history, risk to congestive heart failure, arterial hypertension, and death rate $(p>0.05)$ compared to all other haplotypes. However, we found significantly more HYPD haplotype carriers among the frequent exacerbators $(p=0.01)$ (Table 3). 
Table 3 Frequency of MBL2 haplotypes in relation to exacerbations

\begin{tabular}{|c|c|c|c|c|c|c|}
\hline \multirow[t]{2}{*}{ MBL2 Haplotype } & \multirow[t]{2}{*}{ Expected serum MBL Level } & \multicolumn{2}{|c|}{ Infrequent exacerbation } & \multicolumn{2}{|c|}{ Frequent exacerbation } & \multirow[t]{2}{*}{$p$ value } \\
\hline & & $n$ & Frequency & $n$ & Frequency & \\
\hline HYPA & High & 87 & 0.282 & 85 & 0.346 & 0.13 \\
\hline$\angle Y Q A$ & High & 75 & 0.243 & 53 & 0.215 & 0.49 \\
\hline LYPA & High & 30 & 0.097 & 15 & 0.061 & 0.16 \\
\hline$\angle X P A$ & Intermediate & 71 & 0.230 & 50 & 0.203 & 0.50 \\
\hline$\angle Y P B$ & Low & 27 & 0.087 & 19 & 0.077 & 0.77 \\
\hline HYPD & Low & 10 & 0.032 & 21 & 0.085 & 0.01 \\
\hline$\angle Y Q C$ & Low & 8 & 0.026 & 3 & 0.012 & 0.39 \\
\hline
\end{tabular}

The distribution of haplotypes corresponding to express high to low serum MBL are categorized in infrequent and frequent exacerbation. Here, the HYPD haplotype is significantly higher among frequent exacerbators

\section{Discussion}

In this study, we present three important new findings. Firstly, we found that significantly more $H Y P D$ haplotype carriers, supposed to express low serum MBL levels, were frequent exacerbators. Secondly, serum MBL was neither predictive for COPD severity, exacerbation frequency, nor for bacterial colonization. And finally, low serum MBL at stable state was associated with reduced survival. To our knowledge this is the largest and most comprehensive study assessing both serum MBL and MBL2 haplotypes in Caucasians COPD patients.

It has been argued that COPD exacerbation involves the innate immune response, which is linked to serum MBL, and MBL2 gene polymorphisms [3, 22]. The $M B L 2$ genotypes result from several polymorphisms in both the promoter and exon 1 region and are assumed to modify serum MBL levels $[15,23]$. The promoter allele $X / Y$ was linked with pooled exon $1(A / A, A / O, O / O)$ polymorphisms to form genotypes (e.g. $Y A / Y A, X A / Y O$ ), which account for increased serum MBL. It has been suggested that the promoter $X$ allele causes low expression of MBL, while any polymorphisms in exon 1 were associated with reduced MBL function in Caucasians [24]. Previous studies showed that the most commonly described MBL2 haplotypes (HYPA, LYPA, LXPA, LYQA, $H Y P D, L Y P B, L Y Q C)$ predict susceptibility to various diseases [25-27]. In this COPD cohort we describe for the first time a significant difference for the allele frequency of $H / L$ and $A / D$ in frequent and infrequent exacerbators.

The high frequency of the HYPA (31 \%) haplotype was expected, as it is the most common haplotype among Europeans. However, the LYPB (8 \%) haplotype was less frequent than described elsewhere [28], but was significantly increased in frequent exacerbators. Previous studies found the HYPD haplotype to modulate the risk for liver disease in cystic fibrosis [27, 29], while it was protective against pulmonary tuberculosis [25]. Our data proposes the HYPD haplotype as a marker of frequent exacerbation in COPD, while it was not linked to serum MBL levels. It is indicated that serum MBL $<100 \mathrm{ng} / \mathrm{ml}$ present a deficiency and occurs in $5 \%$ Europeans [30]. In contrast, only $2(0.7 \%)$ patients in our cohort presented serum MBL $<100 \mathrm{ng} / \mathrm{ml}$. Since only MBL sufficient genotypes responded to acute phase reactivity in pneumonia, serum MBL may not significantly increase in patients with MBL deficiency genotypes despite inflammation [31].

In cystic fibrosis, MBL2 levels correlated with reduced FEV1 \% predicted [32]. Conversely, in COPD patients at stable state, we found only a trend for a correlation of serum MBL and $\mathrm{FEV}_{1} \%$ predicted. Herein, the additional lack of association of serum MBL with other COPD parameters such as quality of life, BODE index, exercise capacity, or duration of symptoms supports the notion that serum MBL does not directly relate to the severity of the disease in COPD. It has been reported earlier that MBL deficiency showed no association to COPD severity [33]. Studies have shown that MBL deficiency may have detrimental consequences on the long-term outcomes in chronic granulomatous disease (CGD) [34] and those with variant forms of MBL have a high risk of developing autoimmune disorders [35].

In other diseases, such as cystic fibrosis, it was reported that MBL2 deficiency was associated to infection with Pseudomonas aeruginosa and Burkholderia cepacia [32]. However, in our study, circulating MBL levels in patients with and without bacterial colonisation were similar. Specifically, colonization by Pseudomonas aeruginosa was not associated with lower circulating MBL levels. Therefore, the association of MBL deficiency and Pseudomonas aeruginosa may be disease specific. [32], Regarding the link of MBL alleles and infection susceptibility we found no difference between patients with and without colonization and serum MBL levels, while it was suggested that $Y / Y$ promoter homozygotes are more susceptible to bacterial colonization [36]. MBL2 polymorphisms had been presented to increase the risk of pneumonia and low serum MBL was controversially correlated with an increased risk of bacterial and viral infections [31]. Furthermore, a large study in Caucasian 
showed no association of exon $1 M B L 2$ genotypes and infection [37]. Bacterial surface lipopolysaccharide capsular antigen of Streptococcus pneumoniae causes airway inflammation, stimulating and binding with MBL protein and potentially leading to exacerbations [38]. Another study found the high-MBL expressing HYPA haplotype more frequent among controls than in patients with infection [39]. In isolates from immune-compromised children, MBL protein bound only to a selection of bacteria [40]. Most of these strong MBL binding bacteria were not encountered in the present COPD cohort suggesting a limited involvement in innate immunity. Yang et al. described a significant association between the MBL2-54 $A / B$ allele and reduced serum MBL with infective COPD exacerbation. Unfortunately, exacerbations were not further differentiated for microorganisms [41]. In the present cohort, we observed a better survival in patients with high MBL levels. In accordance with our findings, Dahl et al. reported a higher prevalence of cardiovascular disorders in deficient $M B L 2$ carrier patients [37]. In kidney transplant patients, the low serum MBL haplotypes $X A$ and $Y O$ were also significantly associated with reduced survival [42]. These results are in agreement with a study in the United Kingdom showing that lower circulating MBL level was related to poor disease outcome in septic shock [43]. Although this study lacks the ability to define precise mechanisms of the role of serum MBL to disease pathogenesis, our findings suggest that high serum MBL is protective in COPD.

We have observed that increased MBL levels correlated with increased survival, Shall its protective effect be confirmed in further studies, it would be worthwhile exploring recombinant or purified MBL replacement as a therapeutic strategy in high-risk patients with COPD.

\section{Limitations}

The limitations of this study are: we did not have a control group, which would have added value to this analysis. However, the distribution of $M B L 2$ polymorphisms in our population was similar to that reported in the dbSNP database [44]. We cannot exclude the possibility that an association between deficient MBL2 genotypes and serum MBL concentrations could be evidenced in a population with a different ethnic background and/or larger sample size. There is no consensus in defining deficient serum MBL levels, thus we used the $4^{\text {th }}$ quartile as threshold value. As any data driven definition, this threshold might overestimate any association. Taking in to account that MBL might exert a local effect in the lung, which is not reflected in the serum, it would be of interest to compare serum to BAL samples. However in the setting of this study BAL samples were not collected. The range of MBL in BAL samples is at least 100 times greater than what we observed in serum samples $(\mathrm{ng} / \mathrm{ml} \mathrm{vs} \mathrm{pg} / \mathrm{ml})$.
Therefore the variation in our samples is significantly smaller as compared to that of Hodge et al. [45]. It would be of interest to determine the influence of MASP2 with MBL2 as only the complex of both proteins exerts an anti-bacterial/viral effect. However, to include this data in our cohort we would also have to determine all known polymorphisms for MASP2 and then combine them with all genotypes of MBL2. Similarly, the association between HYPD haplotype and frequent exacerbations should be confirmed in further studies. Nevertheless, the major strength of this study is the detailed patient and disease activity characterisation of a pan-European COPD cohort.

\section{Conclusions}

The major findings of this study suggests that Caucasian COPD patients with the MBL2-HYPD haplotype demonstrate more commonly frequent exacerbations, while high serum MBL at stable state is associated with increased survival.

\section{Additional file}

Additional file 1: Table S1. Distribution of serum MBL level and exacerbation frequency in different "MBL concentration groups". (DOCX $89 \mathrm{~kb})$

\section{Abbreviations}

BD: broncho-dilator; BODE: body mass index, airflow obstruction, dyspnea and exercise capacity; COPD: chronic obstructive pulmonary disease;

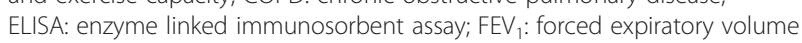
one second; FVC: forced vital capacity; GOLD: global initiative for chronic obstructive lung disease; IQR: interquartile range; MASP: MBL associated serine protease; MBL: mannose binding lectin; PROMISE-COPD: predicting outcome using systemic markers in severe exacerbations of COPD; RTPCR: real time- polymerase chain reaction; SF-36: short form (36) health survey; SGRQ: St. George's respiratory questionnaire; SPSS: statistical package for social sciences.

\section{Competing interests}

All authors declare no competing interests.

\section{Authors' contributions}

All authors contributed in the content and approval of the submitted manuscript. Additionally, JM and BM. contributed in the analysis of clinical data, single nucleotide polymorphisms, statistical tests and interpretations, writing and finalization of the manuscript; JM. contributed in performing MBL ELISA assay, integrity and accuracy of the data; RS. contributed in intellectual content of manuscript, performed MBL2 genotyping, confirmed accuracy of the data; integrity and accuracy of the data; LC. contributed in performing MBL ELISA assay, integrity and accuracy of the data; AE, MT contributed in intellectual content of the manuscript; FB, KK, TWAT, RL, WB, $B M i, J A, G R, A L, L B, J R, A S, K R, J C J, M R$, and, MT had contributed in study design, collected clinical data; Tables and figures were created by BM. with input from DS. DS. was the principal investigator and conceived the research project, contributed in clinical work, validated integrity and accuracy of the data. DS was supported from the Swiss National Foundation (PP00P3_128412/1).

\section{Acknowledgements}

We thank Prof. Jens Christian Jensenius, Department of Biomedicine, Aarhus University, Denmark for his contribution. We thank all general physicians for providing follow-up information. We thank Anja Meyer RN for her outstanding contribution in data management and patient follow-up. 


\section{Author details}

${ }^{1}$ Clinic of Pulmonary Medicine and Respiratory Cell Research, University Hospital Basel, Petersgraben, 44031 Basel, Switzerland. 'Department of Clinical Immunology, Aalborg University Hospital, Aalborg, Denmark. ${ }^{3}$ Infection Disease Department, University Hospital Basel, Basel, Switzerland. ${ }^{4}$ Department of Biomedicine and Division of Internal Medicine, University Hospital Basel, Basel, Switzerland. ${ }^{5}$ Department of Pathophysiology and Transplantation, Università degli Studi di Milano, IRCCS Fondazione Cà Granda Policlinico, Milan, Italy. ${ }^{6}$ Thessaly Medical School, Thessaloniki, Greece. ${ }^{7}$ Medical School Hannover, Hannover, Germany. ${ }^{8}$ Hospital Clinic, Barcelona, Spain. ${ }^{9}$ University of Liege, Liege, Belgium. ${ }^{10}$ Medisch Centrum Alkmaar, Alkmaar, Netherlands. "'Faculty of Medicine, University of Belgrade; Clinic for Pulmonary Diseases, Belgrade, Serbia. ${ }^{12}$ Amphia Hospital, Breda, Netherlands. ${ }^{13}$ Maastricht University Medical Center, Maastricht, The Netherlands. ${ }^{14}$ Department of Microbiology, Hospital Universitari Germans Trias i Pujol, CIBER Enfermedades Respiratorias, Badalona, Spain. ${ }^{15}$ Department of Laboratorial Medicine, University Hospital Basel, Basel, Switzerland.

\section{Received: 10 September 2015 Accepted: 26 November 2015} Published online: 18 December 2015

\section{References}

1. World Health Organization. Burden of COPD. [http://www.who.int/ respiratory/copd/burden/en/s

2. Global Strategy for the Diagnosis, Management and Prevention of COPD. Guidelines. 2015. http://www.goldcopd.org/uploads/users/files/GOLD_ Report_2015_Sept2.pdf

3. Hurst JR, Vestbo J, Anzueto A, Locantore N, Mullerova H, Tal-Singer R, et al. Susceptibility to exacerbation in chronic obstructive pulmonary disease. N Engl J Med. 2010;363:1128-38.

4. Lin CL, Siu LK, Lin JC, Liu CY, Chian CF, Lee CN, et al. Mannose-binding lectin gene polymorphism contributes to recurrence of infective exacerbation in patients with COPD. Chest. 2011:139:43-51.

5. Lacroix M, Dumestre-Perard C, Schoehn G, Houen G, Cesbron JY, Arlaud GJ, et al. Residue Lys57 in the collagen-like region of human L-ficolin and its counterpart Lys47 in H-ficolin play a key role in the interaction with the mannan-binding lectin-associated serine proteases and the collectin receptor calreticulin. J Immunol. 2009;182:456-65.

6. Adamek M, Heyder J, Heinold A, Fiedler G, Opelz G, Tran TH. Characterization of mannose-binding lectin $(\mathrm{MBL})$ variants by allele-specific sequencing of MBL2 and determination of serum MBL protein levels. Tissue Antigens. 2013;82:410-5.

7. Eisen DP. Mannose-binding lectin deficiency and respiratory tract infection. J Innate Immun. 2010;2:114-22.

8. Chalmers JD, McHugh BJ, Doherty C, Smith MP, Govan JR, Kilpatrick DC, et al. Mannose-binding lectin deficiency and disease severity in non-cystic fibrosis bronchiectasis: a prospective study. Lancet Respir Med. 2013;1:224-32.

9. Stolz D, Boersma W, Blasi F, Louis R, Milenkovic B, Kostikas K, et al. Exertional hypoxemia in stable COPD is common and predicted by circulating proadrenomedullin. Chest. 2014;146:328-38.

10. Russi EW, Karrer W, Brutsche M, Eich C, Fitting JW, Frey M, et al. Diagnosis and management of chronic obstructive pulmonary disease: the swiss guidelines. Official guidelines of the swiss respiratory society. Respiration. 2013;85:160-74.

11. Isenberg H. Clinical microbiology procedures handbook. Washington: Blackwell; 1992.

12. Henckaerts L, Nielsen KR, Steffensen R, Van Steen K, Mathieu C, Giulietti $A$, et al. Polymorphisms in innate immunity genes predispose to bacteremia and death in the medical intensive care unit. Crit Care Med. 2009;37:192-201. e1-3.

13. Molle I, Steffensen R, Thiel S, Peterslund NA. Chemotherapy-related infections in patients with multiple myeloma: associations with mannanbinding lectin genotypes. Eur J Haematol. 2006;77:19-26.

14. Hoeflich C, Unterwalder N, Schuett S, Schmolke K, Boenisch O, Hammer M, et al. Clinical manifestation of mannose-binding lectin deficiency in adults independent of concomitant immunodeficiency. Hum Immunol. 2009;70: 809-12.

15. Olesen HV, Jensenius JC, Steffensen R, Thiel S, Schiotz PO. The mannanbinding lectin pathway and lung disease in cystic fibrosis-disfunction of mannan-binding lectin-associated serine protease 2 (MASP-2) may be a major modifier. Clin Immunol. 2006;121:324-31.
16. Garred P, Larsen F, Seyfarth J, Fujita R, Madsen HO. Mannose-binding lectin and its genetic variants. Genes Immun. 2006;7:85-94.

17. Boldt AB, Culpi L, Tsuneto LT, de Souza IR, Kun JF, Petzl-Erler ML. Diversity of the MBL2 gene in various Brazilian populations and the case of selection at the mannose-binding lectin locus. Hum Immunol. 2006;67:722-34.

18. Madsen HO, Garred P, Thiel S, Kurtzhals JA, Lamm LU, Ryder LP, et al. Interplay between promoter and structural gene variants control basal serum level of mannan-binding protein. J Immunol. 1995;155:3013-20.

19. Steffensen R, Thiel S, Varming K, Jersild C, Jensenius JC. Detection of structural gene mutations and promoter polymorphisms in the mannanbinding lectin (MBL) gene by polymerase chain reaction with sequencespecific primers. J Immunol Methods. 2000;241:33-42.

20. Steffensen R, Hoffmann K, Varming K. Rapid genotyping of MBL2 gene mutations using real-time PCR with fluorescent hybridisation probes. J Immunol Methods. 2003;278:191-9.

21. Alves Pedroso ML, Boldt AB, Pereira-Ferrari $L$, Steffensen $R$, Strauss $E$, Jensenius JC, et al. Mannan-binding lectin MBL2 gene polymorphism in chronic hepatitis C: association with the severity of liver fibrosis and response to interferon therapy. Clin Exp Immunol. 2008;152:258-64.

22. Heitzeneder S, Seidel M, Forster-Waldl E, Heitger A. Mannan-binding lectin deficiency - Good news, bad news, doesn't matter? Clin Immunol. 2012;143:22-38.

23. Crosdale DJ, Ollier WE, Thomson W, Dyer PA, Jensenious J, Johnson RW, et al. Mannose binding lectin (MBL) genotype distributions with relation to serum levels in UK Caucasoids. Eur J Immunogenet. 2000;27:111-7.

24. Pine SR, Mechanic LE, Ambs S, Bowman ED, Chanock SJ, Loffredo C, et al. Lung cancer survival and functional polymorphisms in MBL2, an innateimmunity gene. J Natl Cancer Inst. 2007;99:1401-9.

25. Ocejo-Vinyals JG, Lavin-Alconero L, Sanchez-Velasco P, Guerrero-Alonso MA, Ausin F, Farinas MC, et al. Mannose-binding lectin promoter polymorphisms and gene variants in pulmonary tuberculosis patients from cantabria (northern Spain). Pulm Med. 2012;2012:469128.

26. Collard CD, Shernan SK, Fox AA, Bernig T, Chanock SJ, Vaughn WK, et al. The MBL2 'LYQA secretor' haplotype is an independent predictor of postoperative myocardial infarction in whites undergoing coronary artery bypass graft surgery. Circulation. 2007;116:1106-12.

27. Tomaiuolo R, Degiorgio D, Coviello DA, Baccarelli A, Elce A, Raia V, et al. An MBL2 haplotype and ABCB4 variants modulate the risk of liver disease in cystic fibrosis patients: a multicentre study. Dig Liver Dis. 2009;41:817-22.

28. Boldt AB, Messias-Reason IJ, Meyer D, Schrago CG, Lang F, Lell B, et al. Phylogenetic nomenclature and evolution of mannose-binding lectin (MBL2) haplotypes. BMC Genet. 2010;11:38.

29. El-Omar EM, Rabkin CS, Gammon MD, Vaughan TL, Risch HA, Schoenberg $\mathrm{JB}$, et al. Increased risk of noncardia gastric cancer associated with proinflammatory cytokine gene polymorphisms. Gastroenterology. 2003;124:1193-201.

30. Degn SE, Jensenius JC, Thiel S. Disease-causing mutations in genes of the complement system. Am J Hum Genet. 2011;88:689-705.

31. Herpers BL, Endeman $H$, de Jong BA, de Jongh BM, Grutters JC, Biesma DH, et al. Acute-phase responsiveness of mannose-binding lectin in communityacquired pneumonia is highly dependent upon MBL2 genotypes. Clin Exp Immunol. 2009;156:488-94.

32. Chalmers JD, Fleming GB, Hill AT, Kilpatrick DC. Impact of mannose-binding lectin insufficiency on the course of cystic fibrosis: A review and metaanalysis. Glycobiology. 2011;21:271-82.

33. Eagan TM, Aukrust P, Bakke PS, Damas JK, Skorge TD, Hardie JA, et al. Systemic mannose-binding lectin is not associated with chronic obstructive pulmonary disease. Respir Med. 2010;104:283-90.

34. Watkins C, Saleh H, Song E, Jaishankar GB, Chi DS, Misran N, et al. Concomitant gene mutations of MBL and CYBB in chronic granulomatous disease: implications for host defense. Inflamm Allergy Drug Targets. 2012;11:222-6.

35. Foster CB, Lehrnbecher T, Mol F, Steinberg SM, Venzon DJ, Walsh TJ, et al. Host defense molecule polymorphisms influence the risk for immunemediated complications in chronic granulomatous disease. J Clin Invest. 1998;102:2146-55.

36. Rantala A, Lajunen T, Juvonen R, Bloigu A, Silvennoinen-Kassinen S, Peitso A, et al. Mannose-binding lectin concentrations, MBL2 polymorphisms, and susceptibility to respiratory tract infections in young men. J Infect Dis. 2008;198:1247-53. 
37. Dahl M, Tybjaerg-Hansen A, Schnohr P, Nordestgaard BG. A populationbased study of morbidity and mortality in mannose-binding lectin deficiency. J Exp Med. 2004;199:1391-9.

38. van Kessel DA, Hoffman TW, van Velzen-Blad H, Zanen P, Rijkers GT, Grutters JC. Response to pneumococcal vaccination in mannose-binding lectindeficient adults with recurrent respiratory tract infections. Clin Exp Immunol. 2014;177:272-9.

39. Scudiero O, Monaco ML, Nigro E, Capasso M, Guida M, Di Spiezio SA, et al. Mannose-binding lectin genetic analysis: possible protective role of the HYPA haplotype in the development of recurrent urinary tract infections in men. Int J Infect Dis. 2014;19:100-2.

40. Neth O, Jack DL, Dodds AW, Holzel H, Klein NJ, Turner MW. Mannosebinding lectin binds to a range of clinically relevant microorganisms and promotes complement deposition. Infect Immun. 2000;68:688-93.

41. Yang IA, Seeney SL, Wolter JM, Anders EM, McCormack JG, Tunnicliffe AM, et al. Mannose-binding lectin gene polymorphism predicts hospital admissions for COPD infections. Genes Immun. 2003:4:269-74.

42. Bay JT, Sorensen SS, Hansen JM, Madsen HO, Garred P. Low mannosebinding lectin serum levels are associated with reduced kidney graft survival. Kidney Int. 2013;83:264-71.

43. Gordon AC, Waheed U, Hansen TK, Hitman GA, Garrard CS, Turner MW, et al. Mannose-binding lectin polymorphisms in severe sepsis: relationship to levels, incidence, and outcome. Shock. 2006;25:88-93.

44. Sherry ST, Ward MH, Kholodov M, Baker J, Phan L, Smigielski EM, et al. dbSNP: the NCBI database of genetic variation. Nucleic Acids Res. 2001:29:308-11.

45. Hodge $\mathrm{S}$, Hodge $\mathrm{G}$, Jersmann $\mathrm{H}$, Matthews $\mathrm{G}$, Ahern J, Holmes $\mathrm{M}$, et al. Azithromycin improves macrophage phagocytic function and expression of mannose receptor in chronic obstructive pulmonary disease. Am J Respir Crit Care Med. 2008;178:139-48.

\section{Submit your next manuscript to BioMed Central and we will help you at every step:}

- We accept pre-submission inquiries

- Our selector tool helps you to find the most relevant journal

- We provide round the clock customer support

- Convenient online submission

- Thorough peer review

- Inclusion in PubMed and all major indexing services

- Maximum visibility for your research 